\title{
Cranial nerve involvement in infratentorial progressive multifocal leukoencephalopathy
}

Figure MRI findings in infratentorial progressive multifocal leukoencephalopathy with cranial nerve involvement

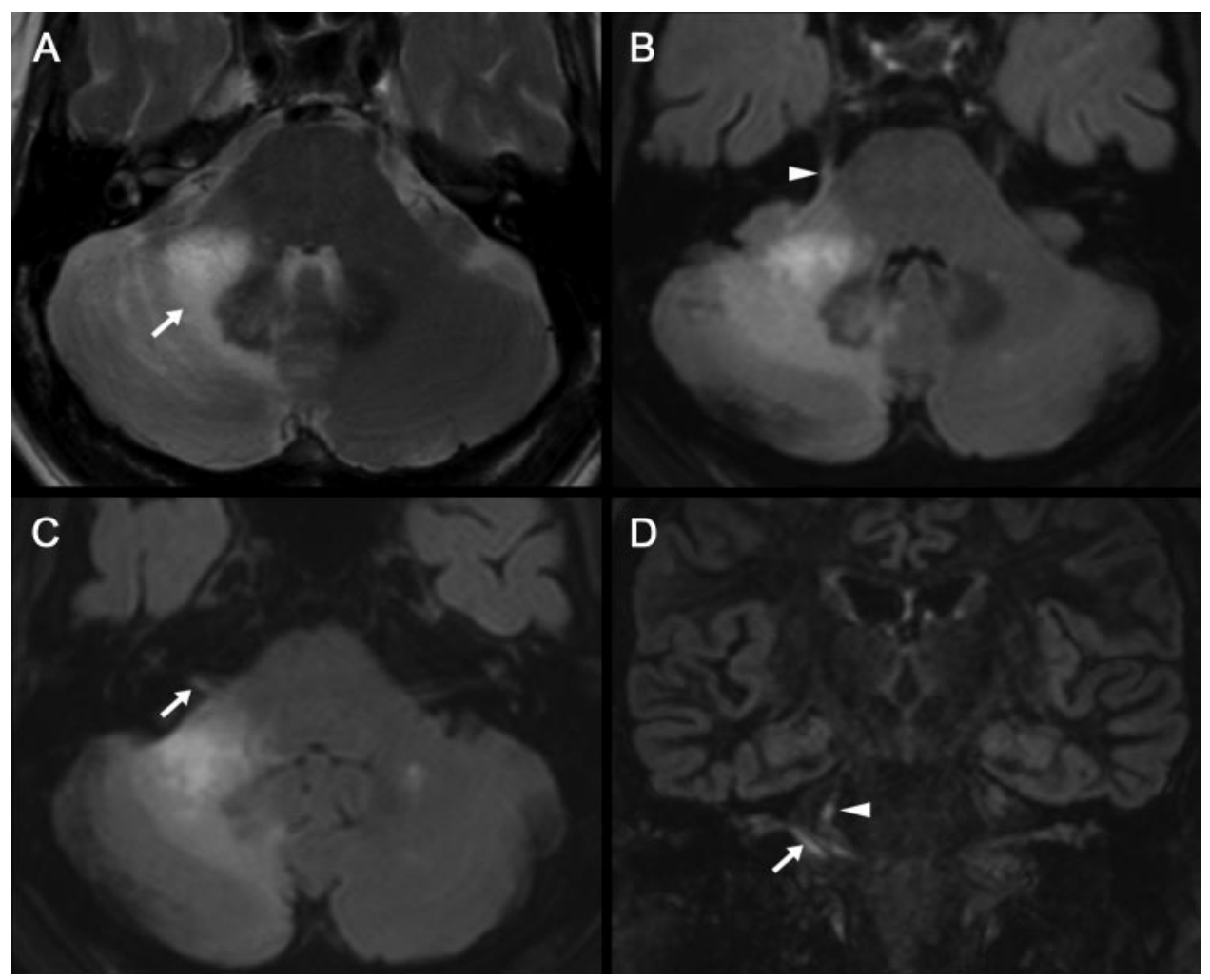

The lesion showed hyperintensity on T2-weighted sequence (A) without mass effect (arrows). Both fluid-attenuated inversion recovery $(B, C)$ and double inversion recovery $(D)$ sequences confirmed the additional involvement of right cranial nerves V (arrowhead) and VIII (arrow).

A 71-year-old man presented with right hypoacusis following immunosuppressive therapy after liver transplantation.

MRI demonstrated T1-hypointense and T2-hyperintense white matter lesions involving the right middle cerebellar peduncle, adjacent pons, and cerebellum, consistent with progressive multifocal leukoencephalopathy (PML), confirmed with PCR in a CSF sample. Fluid-attenuated inversion recovery and double inversion recovery sequences revealed involvement of right cranial nerves $\mathrm{V}$ and VIII (figure).

CSF revealed normal cell counts, glucose, and protein. PCR for herpesviruses and toxoplasmosis and CSF culture for Mycobacterium tuberculosis, Listeria monocytogenes, and Cryptococcus neoformans were negative. Chest and abdominal CT were normal.

In PML, infratentorial white matter is a common area of involvement. ${ }^{1,2}$ Our patient suggests cranial nerve involvement is possible.

Jérôme Hodel, MD, Lille and Paris; Olivier Outteryck, MD, Hélène Zéphir, MD, Lille; Mathieu Rodallec, MD, Marc Zins, MD, Paris; Patrick Vermersch, MD, PhD, and Xavier Leclerc, MD, PhD, Lille, France

Author contributions: Dr. Hodel: drafting/revising the manuscript, analysis or interpretation of data, acquisition of data. Dr. Outteryck: drafting/revising the manuscript, study concept or design, analysis or interpretation of data. Dr. Zéphir: drafting/revising the 
manuscript. Dr. Rodallec: drafting/revising the manuscript, analysis or interpretation of data, study supervision. Dr. Zins: drafting/ revising the manuscript. Dr. Vermersch: drafting/revising the manuscript, analysis or interpretation of data, acquisition of data. Dr. Leclerc: drafting/revising the manuscript, analysis or interpretation of data.

Dr. Hodel reports no disclosures. Dr. Outteryck has received funding for travel from Biogen Idec, Bayer Schering Pharma, Merck Serono, Novartis, Teva Pharmaceutical Industries Ltd, and Sanofi-Aventis and for speaker honoraria from Bayer Schering Pharma, Biogen Idec and Sanofi-Aventis. Dr. Zéphir has received funding for travel from Biogen Idec, Bayer Schering Pharma, Merck Serono, Novartis, Teva Pharmaceutical Industries Ltd, and Sanofi-Aventis and for speaker honoraria from Bayer Schering Pharma, Biogen Idec, Teva Pharmaceutical Industries Ltd, and Sanofi-Aventis. Dr. Rodallec and Dr. Zins report no disclosures. Dr. Vermersch serves on scientific advisory board for Biogen Idec, Bayer Schering Pharma, Merck Serono, Novartis, Teva Pharmaceutical Industries Ltd, Almirall, and Sanofi-Aventis; has received funding for travel and speaker honoraria from Biogen Idec, Bayer Schering Pharma, Novartis, Teva Pharmaceutical Industries Ltd, Sanofi-Aventis, and Merck Serono; and receives research support from Biogen Idec, Merck Serono, Sanofi-Aventis, Teva Pharmaceutical Industries Ltd, and Bayer Schering Pharma. Dr. Leclerc reports no disclosures. Go to Neurology.org for full disclosures.

Correspondence \& reprint requests to Dr. Hodel: jerome.hodel@hmn.aphp.fr

1. Whiteman ML, Post MJ, Berger JR, Tate LG, Bell MD, Limonte LP. Progressive multifocal leukoencephalopathy in 47 HIV-seropositive patients: neuroimaging with clinical and pathologic correlation. Radiology 1993;187:233-240.

2. Bag AK, Cure JK, Chapman PR, Roberson GH, Shah R. JC virus infection of the brain. AJNR Am J Neuroradiol 2010;31: 1564-1576.

\section{NeuroImages Are Free at www.neurology.org!}

All Neurology ${ }^{\circledR}$ NeuroImages can now be freely accessed on the Neurology Web site. See them at www.neurology.org, where you can also sign up for journal email alerts and check out other online features, including the Resident \& Fellow section, Neurology: Clinical Practice, and the weekly Neurology Podcasts. 


\section{Neurology}

\section{Cranial nerve involvement in infratentorial progressive multifocal leukoencephalopathy}

Jérôme Hodel, Olivier Outteryck, Hélène Zéphir, et al. Neurology 2012;79;104-105

DOI 10.1212/WNL.0b013e31825dce72

\section{This information is current as of July 2, 2012}

\section{Updated Information \&} Services

References

Subspecialty Collections

Permissions \& Licensing

Reprints including high resolution figures, can be found at: http://n.neurology.org/content/79/1/104.full

This article cites 2 articles, 1 of which you can access for free at: http://n.neurology.org/content/79/1/104.full\#ref-list-1

This article, along with others on similar topics, appears in the following collection(s):

All Demyelinating disease (CNS)

http://n.neurology.org/cgi/collection/all_demyelinating_disease_cns MRI

http://n.neurology.org/cgi/collection/mri

Viral infections

http://n.neurology.org/cgi/collection/viral_infections

Information about reproducing this article in parts (figures,tables) or in its entirety can be found online at:

http://www.neurology.org/about/about_the_journal\#permissions

Information about ordering reprints can be found online:

http://n.neurology.org/subscribers/advertise

Neurology ${ }^{\circledR}$ is the official journal of the American Academy of Neurology. Published continuously since 1951, it is now a weekly with 48 issues per year. Copyright Copyright $@ 2012$ by AAN Enterprises, Inc.. All rights reserved. Print ISSN: 0028-3878. Online ISSN: 1526-632X.

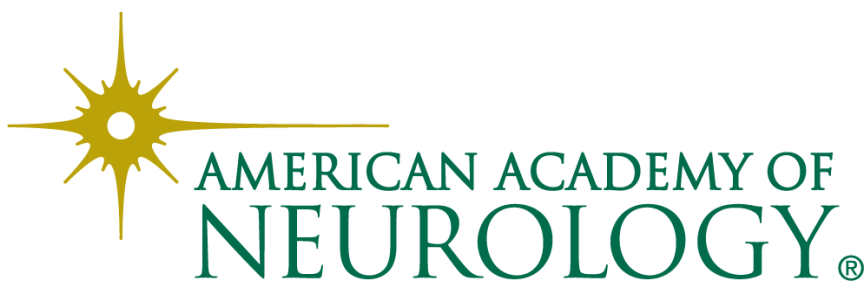

